\title{
Energy efficient improvement of an office building model.
}

\author{
Author: Fraga De Cal B. ${ }^{1}$ \\ ${ }^{1}$ Department of Industrial II Engineering \\ E.P.S., A Coruña University \\ Campus of Esteiro - 15403 Ferrol (Spain) \\ Phone/Fax number: +34 981337400 (3282), e-mail: p.fraga@udc.es
}

\begin{abstract}
A Building Information Model (BIM) is designed to analyse and improve the energy efficiency of an existing building of offices in Madrid, Spain. Three models are compared in order to reduce energy consumption and meet the current European legal framework. Firstly, lighting and insulation are considered to improve at least $10 \%$ the energy efficiency of the building. Then, a reversible Heat Pump is fed by photovoltaic panels working along with a Heat Recovery Ventilation System. Furthermore, a biomass boiler is implemented to provide underfloor heating to substitute former fan coils. The aim is to meet in excess $40 \%$ of energy demand with a renewable source. It is concluded a reduction of $11.14 \%$ in the energy demand by adding an air cavity wall, roof insulation, Argon gas gap in windows and low consumption lighting. Furthermore, the addition of the biomass boiler along with the underfloor heating resulted in a he heat load reduction of $33.07 \%$
\end{abstract}

Keywords: BIM, Heat Pump, Heat Recovery Ventilation System, biomass, renewable sources.

\section{Introduction.}

Increasing greenhouse gas emissions, growing concerns about oil reserves and set targets by Kyoto Protocol have brought the debate about climate change to the forefront. That is why raising awareness about the environmental challenges lying ahead has become essential for our societies.

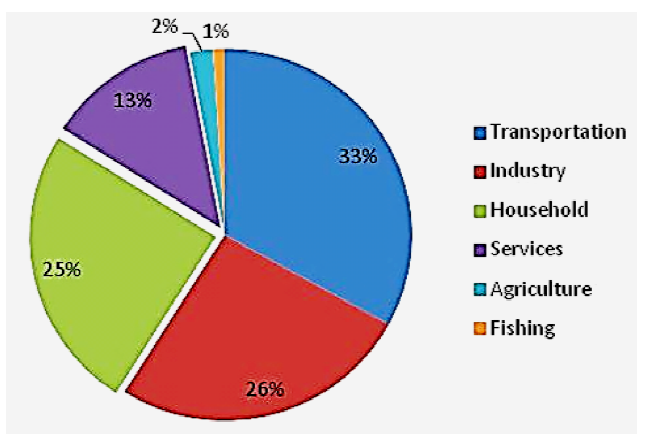

Figure 1. [1] Energy Consumption by sector in European Union.

This environmental and energy saving awareness is leading to end-users and manufacturers considering sustainable construction. Furthermore, government approved that all new buildings of Member States should be almost Zero-Energy Buildings (nZEB) [2], which means reducing energy needs and consumption in addition to install renewable sources supply. The goal is to gain net balance energy in building [3].

According to the last report of European Commission, Figure 1, nearly two fifths of the final energy consumption and gas emission are owing to buildings, both residential and tertiary sector buildings [1]. That figure is higher than the expenditure energy from industry. International Energy Agency points out the significance of examining the existing opportunities of any building to apply renewable energy resources and energy efficiency remedies [4].

Particularly, offices buildings in Spain are the main responsible for energy consumption of tertiary sector. The most striking figure is that the percentage dedicated to heating and cooling in that sector is more than half of the total amount of energy used, accounting for $57.3 \%$. [5] Therefore, developing technologies and systems in order to save energy in offices building it is a matter of necessity for meeting the goals of European Energy Commission.

In this context, this report presents the energy study and thermal simulation of a News Agency offices building located in Madrid, Spain, and constructed in 2012 according to the following regulatory framework

- Royal Decree 1027/2007 of 20 of July and further modifications, which approves Regulation of Thermal Installations in Buildings (RITE-Spain).

- Royal Decree 314/2006 of17 of March and further modifications, which approves Construction Technical Code (CTE-Spain).

\section{Objectives}

The overall aim of this project is to implement effective solutions to help reducing the energy demand of a designed building meeting DB HS-4 from CTE [6]. 
Hence, there are four main purposes in this report to upgrade that building:

- Computational design of a building with its corresponding HVAC system.

- Building Energy Simulation to assess the energy demand by considering meteorological conditions, orientation, materials' ${ }^{\prime}$ thermal conductivity and thermal loads.

- Comparison of the energy performance of the former building and the redesigned building.

\section{Former building design}

The building design was developed to obtain a large level of thermal comfort including precise occupancy profiles. Climate conditions are taken from American Society of Heating, Refrigerating and Air Conditioning Engineers handbook (ASHRAE).

As can be seen on Table 1, Madrid experiences Mediterranean and dry climate, with cold winters and hot summers. The difficulty of that weather is that any strategy that benefits the thermal comfort in an extreme winter, will work against summer conditions because of oscillations temperature.

Table 1. Weather conditions and location

\begin{tabular}{|l|c|c|c|}
\hline $\begin{array}{l}\text { General parameters } \\
\text { Madrid } \\
\text { latitude }\end{array}$ & $40.3^{\circ} \mathrm{C}$ & $\begin{array}{c}\text { Unfavourable weather condition } \\
\text { Summer }\end{array}$ & $\begin{array}{c}\text { Winter } \\
\text { Indoor }\end{array}$ \\
\hline Altitude & 655 & $\begin{array}{c}\text { Indoor } \\
\text { temperature } 24^{\circ} \mathrm{C}\end{array}$ & $\begin{array}{c}\text { temperature } \\
21^{\circ} \mathrm{C}\end{array}$ \\
\hline $\begin{array}{l}\text { Dairy } \\
\text { average } \\
\text { oscillation }\end{array}$ & $15.8^{\circ} \mathrm{C}$ & $\begin{array}{c}\text { Outside } \\
\text { temperature } \\
\text { summer } 39^{\circ} \mathrm{C}\end{array}$ & $\begin{array}{c}\text { Outside } \\
\text { temperature } \\
-3.7^{0} \mathrm{C}\end{array}$ \\
\hline $\begin{array}{l}\text { Annual } \\
\text { average } \\
\text { oscillation }\end{array}$ & $39.7^{0} \mathrm{C}$ & & \\
\hline
\end{tabular}

The offices occupy an area of $217.26 \mathrm{~m}^{2}$ and consist of two floors (Figure 2) such that:

- Ground floor: it was defined seven different surfaces: two offices, one IT print services room, one toilet, one meeting room and one hall. There are six wall fan coils units and two ceiling fan coil units with their pipes and air ducts associated.

- First floor: this level is designated for three offices, one small hall and one toilet. Three wall fan coils and two ceiling fan coils with their pipes and air ducts associated are placed in this storey

- Roof: a reversible Air to Water Heat Pump and the Heat Recovery System are set on the top of the roof with their respective air ducts associated.

The Heating, Ventilation and Air Conditioner system (HVAC) is mainly divided in two facilities:

- Air Source Heat Pump (ASHP) with Fan Coil System which delivers cool or hot air to the rooms. Every Fan Coil Unit is compound by an exchanger and a fan. Air is supplied through that exchanger where chilled or warm water is moving and coming from heat pump.

- Heat Recovery Ventilation: Recirculation indoor air is mandatory to air quality and to save energy as well.

This system consists of an air to air exchanger. Its function is removing the used air and then replaces it to clean outside air. It takes advantage of thermal energy achieved inside and in the exchanger is transferred to the new fresh air. In other words, we benefit from thermal properties of output air and at the same we ventilate the local.

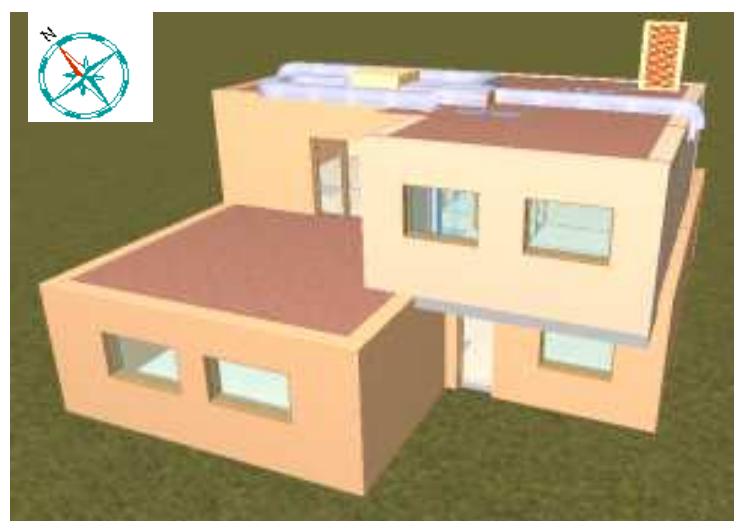

Figure 2. Three-dimensional view of the building

\section{A. Thermal loads.}

A thermal load is each activity that produces changes in temperature and relative humidity of air inside the building. To determine thermal loads is necessary to define a series of parameters:

- Outdoor data: climate conditions, direction and location of every single facade. These figures allow calculating solar radiation, dry and wet bulb temperature and relative humidity.

- Building enclosure: walls, windows, doors, top and floor slabs and roof. Those elements are the main base of houses insulation.

- Internal loads: define the type of room with its corresponding lighting, ventilation and occupancy.

\section{B. Energy demand.}

Energy Plus software estimates the heat transfer process by conduction through materials edifice, air convection and solar radiation according to the input data of thermal loads.

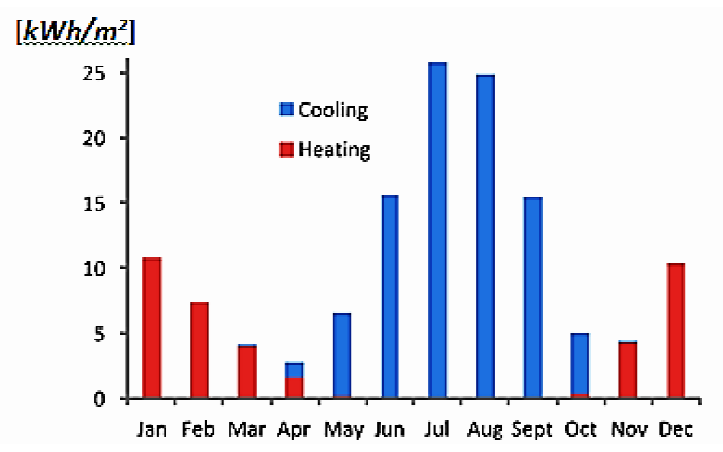

Figure 3. Annual energy demand of the former building 
As a result of the model simulation, it can be seen from Figure 3 and annual energy demand that the building requires more refrigeration than heating significantly.

Table 2. Annual energy demand

\begin{tabular}{|c|c|c|c|}
\hline Energy demand & Area $\left(\mathbf{m}^{2}\right)$ & $\mathbf{k W h} / \mathbf{m}^{2}$ & Annual $\mathbf{k W h}$ \\
\hline Heating & 217.26 & 39.08 & 9622.93 \\
\hline Cooling & 217.26 & 94.12 & 15933.05 \\
& Total & & $\mathbf{2 5 , 5 5 5 . 9 9}$ \\
\hline
\end{tabular}

\section{Insulation upgrade}

The building energy requirements are optimised by improving factors below:

- External Wall: addition of $5 \mathrm{~cm}$ air cavity wall that acts as heat storage and reduces the cool demand.

- Flat Roof. The heat transfer coefficient halved because of a sand and stone layer and the rise of the insulation.

- Ceiling. Increment of the cavity wall insulation, air ventilation and rock wool. Thus, the heat transfer coefficient declined by $0.04 \mathrm{~W} / \mathrm{m}^{2} \mathrm{~K}$.

- Windows. The air gap of the double glazing was replaced by Argon gas. The density of this gas is heavier than air which means that the effect of convection currents is lower. Furthermore, the glass window suggested is tinted in order to absorb sunlight.

- Lighting. Fluorescent lights based on an electronic circuit are suggested. The improvement is because of a magnetic fluorescent is a transformer and consumes electricity and causes heat losses.

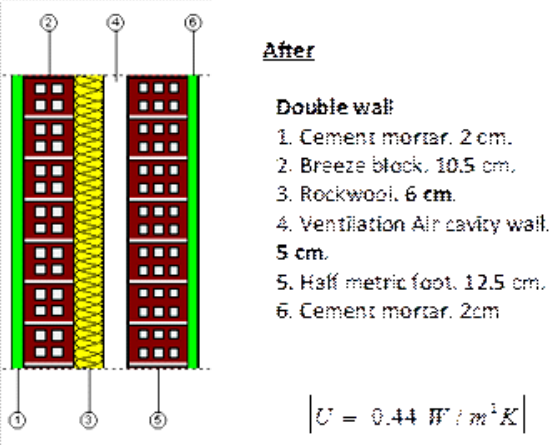

Figure 4. External wall upgraded

\section{Addition of Renewable Sources.}

The third solution was to change the HVAC system. Figure 5 and Figure 6 show the building model and schematic with the new system integrated including:

- Heating. Under floor heating and biomass boiler

- Cooling. ASHP is used as a backup of the Heat Recovery ventilation

- Photovoltaic panels to supply electricity to the ASHP

Heat pumps performance depends substantially on thermal rise between outside and indoor temperature.
Therefore, it is not worthwhile for extreme weather conditions. The temperature difference in summer can be $15^{\circ} \mathrm{C}$ while in winter can be even $24.7^{\circ} \mathrm{C}$, Table 1 . The maximum thermal rise for underfloor heating is set by $5^{\circ} \mathrm{C}$ and water is heated up to $35^{\circ} \mathrm{C}$.

\section{Electricity supply.}

Solar cells are proposed to supply part of the electricity to ASHP. The system is composed by photovoltaic cells (PV), a charge controller and batteries which require an inverter to convert direct current to alternating current (DC 48V/ AC230V).

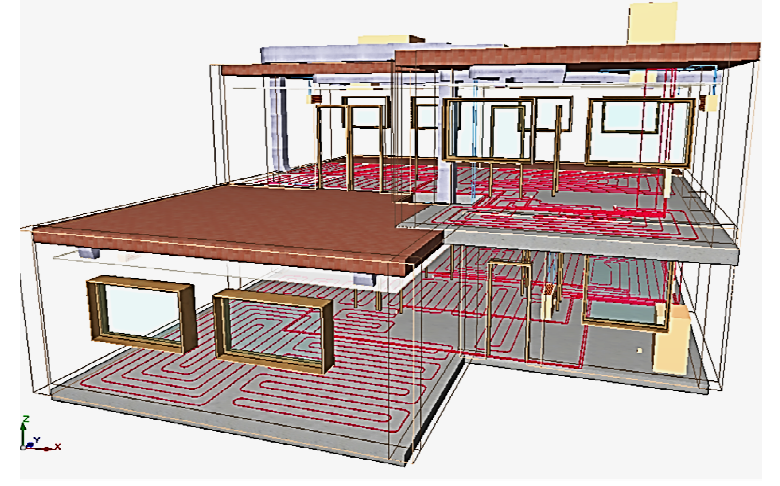

Figure 5. View of the underfloor heating, biomass boiler and air conditioner.

PVs must be designed in south-facing ceilings due to Spain is located in northern hemisphere and the maximum solar radiation is towards the Equator. The inclination of the panels must be as identical as possible to the northern latitude in question. In Madrid case $40.5^{\circ} \mathrm{N}$.

PVsyst software was used to size the facility. This programme considers the sunlight in the particular location and one can obtain energy supply from them, (Table 3).

Table 3. Photovoltaic system features

\begin{tabular}{|r|c|c|c|c|}
\hline $\begin{array}{r}\text { Average use } \\
\text { of energy }\end{array}$ & $\begin{array}{c}\text { Daily } \\
\text { Loss of load }\end{array}$ & $\begin{array}{c}\text { Time } \\
\text { kWh }\end{array}$ & $\begin{array}{c}\text { Yearly } \\
\text { fraction }\end{array}$ & $\begin{array}{c}3796 \\
\mathrm{kWh}\end{array}$ \\
\hline Battery system & $\begin{array}{c}\text { Missing } \\
\text { energy }\end{array}$ & $\begin{array}{c}720 \\
\mathrm{kWh}\end{array}$ \\
\hline & Voltage & $48 \mathrm{~V}$ & Capacity & $\begin{array}{c}3971 \\
\mathrm{~kW}\end{array}$ \\
\hline Nominal power & $\begin{array}{c}5.13 \\
\mathrm{kWp}\end{array}$ & $\begin{array}{c}\text { Nominal } \\
\text { current }\end{array}$ & $82 \mathrm{~A}$ & \\
\hline
\end{tabular}

Seventeen solar cells of $310 \mathrm{Wp}(5.27 \mathrm{kWp})$ are required. Each panel dimension is $2152 \times 1252 \times 93 \mathrm{~mm}$ and the separation among them is $2.89 \mathrm{~m}$ to prevent shadows. This distance depends on the location.

Figure 7 illustrates the battery storage required monthly against to the ASHP cooling demand. This system meets 3,819 $\mathrm{kWh} /$ year of the energy demand. So, removing that from the overall unit cooling demand,

$$
\underbrace{14813.66 \mathrm{kWh}}_{\begin{array}{c}
\text { Electricity consumed } \\
\text { in project 1. }
\end{array}}-\underbrace{3819 \mathrm{kWh}}_{\begin{array}{c}
\text { Electricity provided } \\
\text { by PVsystem }
\end{array}}=\underbrace{10994 \mathrm{kWh}}_{\text {Current needed electricity }}
$$




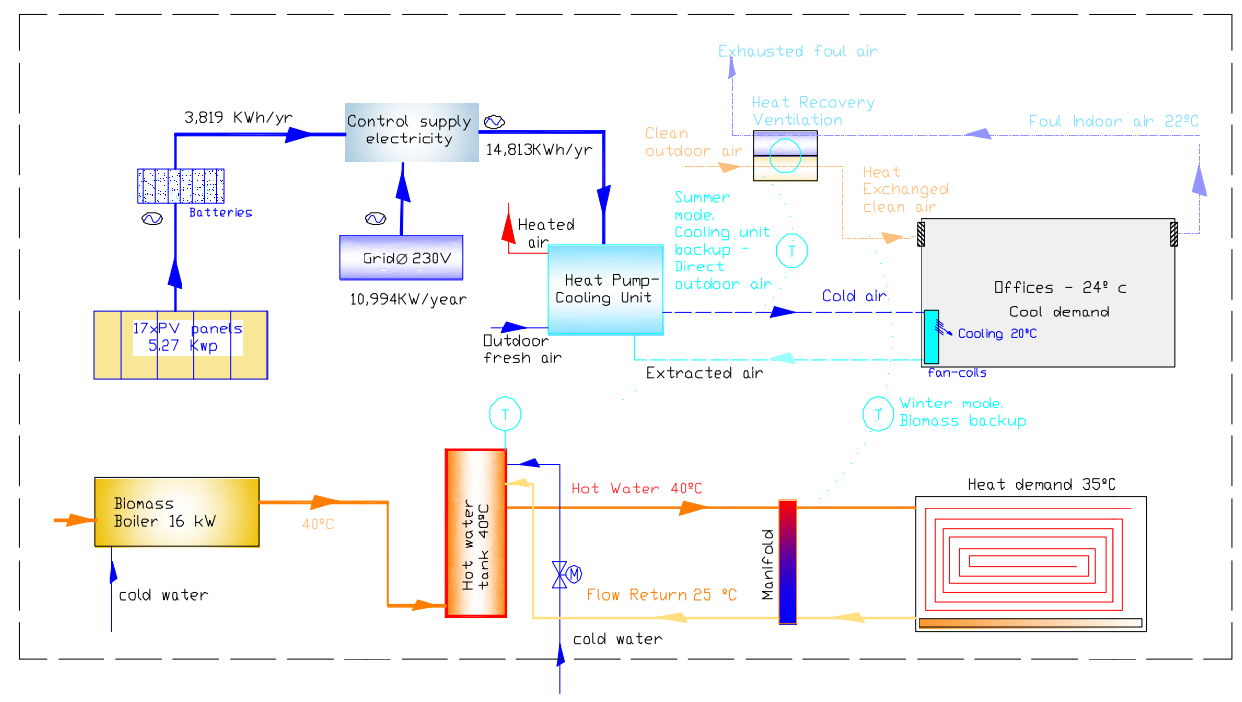

Figure 6. Schematic of the proposed system

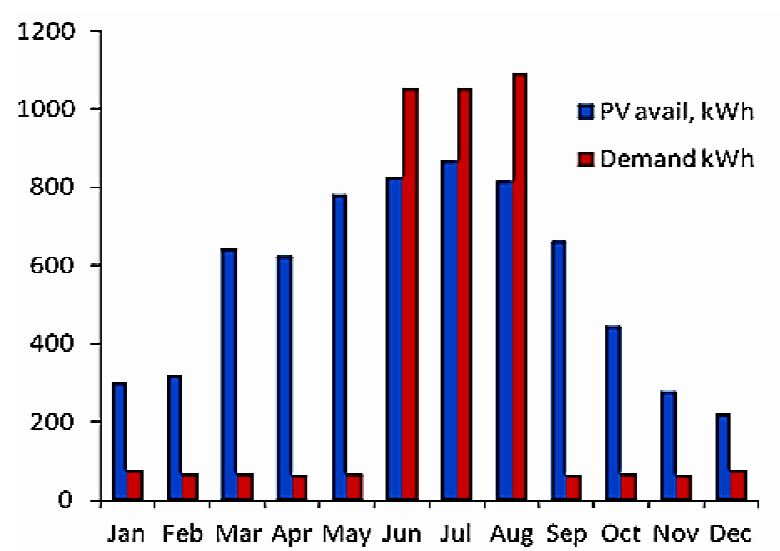

Figure 7. . PVs energy supply

Finally,

$$
\underbrace{3819 \mathrm{kWh}}_{\text {Solar energy }}+\underbrace{4434.37 \mathrm{kWh}}_{\text {Biomass energy }}=8253.37 \mathrm{kWh}
$$

\section{Results}

Any well insulated building consumes less energy, since retains better the indoor temperature. The goal of insulating a building is to increase the thermal

resistances of its external elements by adding insulating materials in walls, ceiling, floors and windows. After the previous structural modifications in addition to lighting changes, annual energy demand is reduced by $11.14 \%$.

Accordingly, shows clearly this reduction. Also, it can be seen from figures below that ventilation and occupancy are the largest loads. The second highest loads are windows and lighting.
Regarding the implementation of the Renewable Energy System, it lead to a $33.07 \%$ drop of energy savings. Furthermore, the energy demand decreased to to $19,248.03 \mathrm{kWh} /$ year. Table 6 shows the notable efficiency of underfloor heating in comparison to airwater heat pump. The main advantage of underfloor heating is that the floor becomes the heat emitter. Thus, thermal comfort is higher than conventional radiators.

The PV system plus the Biomass boiler demonstrated that $42.88 \%$ of the energy demand, $(19248.03 \mathrm{kWh} /$ year) is provided by renewable energies.

\section{Economic feasibility}

Assuming the electricity rate data shown in Table 4, taken from a Spanish electric company [7], we obtain that in the former building the electricity annual bill would be $5929 € /$ year.

$$
\underbrace{28758.59 \mathrm{kWh}}_{\begin{array}{l}
\text { Project } 1 \\
\text { overall energy demand }
\end{array}} \cdot 0.17 \text { Euros/kWh }
$$

Table 4. Electricity rate

\begin{tabular}{|l|c|c|}
\hline Electricity & Rate & Euros/year \\
\hline Company fixed charge & 86.65 & 1039.90 \\
\hline Energy & 0.1770782 & 4889 \\
\hline & Total & $\mathbf{5 9 2 9} € /$ year \\
\hline
\end{tabular}

With regard to energy coming from renewable energy system of the last project suggested,

$$
\frac{10994.66 \mathrm{kWh} * 0.17 € / \mathrm{kWh}}{\text { electricity for unit cooling system }}+
$$




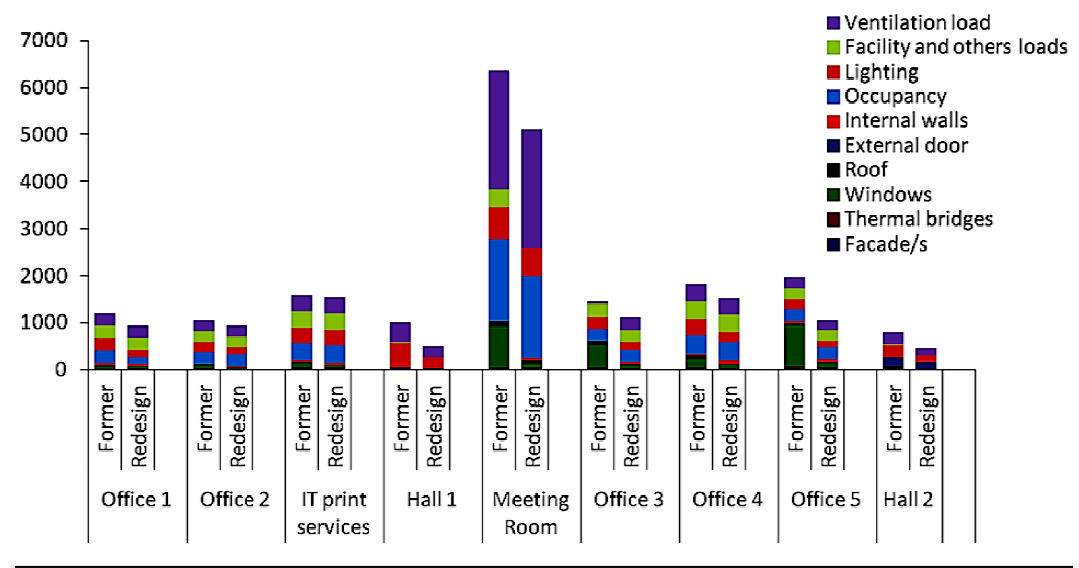

Figure 8. Thermal loads for cooling.

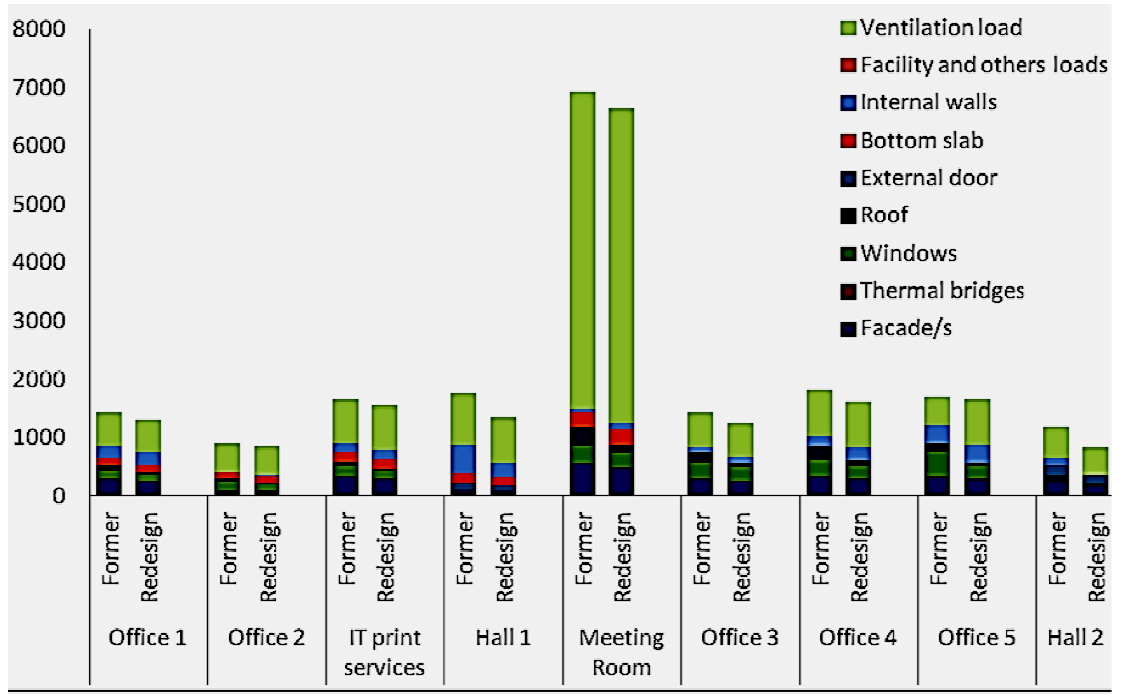

Figure 9. Thermal loads for heating.

The payback period is studied by Taking prices from a construction database of Madrid. The overall cost of the project including renewable energy is,

$$
\underbrace{16586.42}_{\begin{array}{c}
\text { Underfloor heating } \\
\text { and biomass boiler }
\end{array}}+3 \underbrace{4787.35}_{\text {PV system }}+\underbrace{37458.34}_{\text {Cooling unit }}=88832.11^{€}
$$

As we aim to compare two different projects, above investment is considered and the cost of the former building is subtracted. Hence, looking at the table below, the project will show benefits after seven years we would start getting the money back.

Table 5. Playback period

\begin{tabular}{|l|c|c|c|c|}
\hline & 2016 & 2017 & 2018 & 2019 \\
\hline Expenses $€$ & & 0 & 0 & 0 \\
\hline Proposed Project & 88832,11 & 0 & 0 & 0 \\
\hline Current Project & $44.346,76$ & 0 & 0 & 0 \\
\hline Subtraction) Total $€$ & 44485,35 & 0 & 0 & 0 \\
\hline Energy Profit & 3910,1 & 4301,11 & 4731,22 & 5204,34 \\
\hline TOTAL $€$ & $-40575,25$ & $-36274,14$ & $-31542,92$ & $-26338,58$ \\
\hline
\end{tabular}

\begin{tabular}{|c|c|}
\hline 2022 & 2023 \\
\hline 0 & 0 \\
\hline 0 & 0 \\
0 & 0 \\
\hline 0 & 0 \\
\hline 6926,98 & 7619,68 \\
\hline$-7389,56$ & 230,12 \\
\hline
\end{tabular}

* Assumptions. 1. Maintenance cost is negligible. 2. As electricity prices increase by $10 \%$ yearly, the energy profit grows this percentage each year. 
Table 6 describes an overview of the improvement of the two projects.

\section{Conclusions}

The building studied is a relatively new building and meet the current regulatory framework related to energy efficiency. However, there are still feasible solutions that would achieve a Zero-Energy building.

Firstly, adding insulation layer to the structure of the building, replacing fluorescents with magnetic reactance and changing the colour and the gas gap of glazing would led to energy efficiency growth of $11.14 \%$.
After that, the integration of under floor heating coming from the biomass boiler become a significant energy saving. This replacement would bring $33.07 \%$ of energy efficiency in comparison with the former building. Then, taking into account the reduction of energy demand, this facility would supply $23.03 \%$ of the new demand. So, in order to increase this percentage PV system was installed. It was necessary to place 17 solar cells to obtain $3819 \mathrm{kWh}$.

The PV integration as well as the biomass boiler would cover $42.88 \%$ of energy demand. Despite that this investment would be considerably high, they they are the most proper facility in terms of energy saving. Finally, after seven years we would started to recover the money invested.

Table 6. Projects comparison

\begin{tabular}{|c|c|c|}
\hline & $\begin{array}{l}\text { Former building } \\
\text { Former Proyect }\end{array}$ & Renewable energy source Proyect. \\
\hline & \multicolumn{2}{|c|}{ Energy demand (kWh/year) } \\
\hline Annual cooling energy demand & 15933.05 & 14813.66 \\
\hline Annual heating energy demand & 9622.93 & 4434.37 \\
\hline Overall annual energy demand & 25555.99 & 19248.03 \\
\hline \multirow[t]{2}{*}{ Energy saving } & 0 & $33.07 \%$ \\
\hline & \multicolumn{2}{|r|}{ Installed power $(\mathrm{kW})$} \\
\hline Reversible air-water Heat pump. Heating & 18 & 0 \\
\hline Reversible air-water Heat pump. Cooling & 19.9 & 0 \\
\hline \multirow[t]{2}{*}{ Air-water unit cooling } & 0 & 18 \\
\hline & \multicolumn{2}{|c|}{ Renewable energy $(\mathbf{k W})$} \\
\hline Wood-pellet boiler & 0 & 16 \\
\hline \multirow{2}{*}{ Photovoltaic panels } & 0 & $5.27 \mathrm{kWp}$ \\
\hline & \multicolumn{2}{|r|}{ Power supply (kWh/year) } \\
\hline Not renewable & 25555.99 & 10994.66 \\
\hline Biomass & 0 & 4434.37 \\
\hline Solar photovoltaic & 0 & 3819 \\
\hline $\begin{array}{l}\% \text { renewable energy for the energy } \\
\text { demand of the building }\end{array}$ & 0 & $42.88 \%$ \\
\hline
\end{tabular}

\section{References}

[1] Eurostat, "EU energy in figures," Publications Office of the European Union, Luxembour, 2013.

[2] European Parliament and of the Council, "Energy performance of buildings," Official Journal of the European Comission, pp. 14-35, 2010.

[3] International Energy Agency, "Modernising Building Energy Codes," France, 2010.

[4] International Energy Agency (IEA), “The multiple benefits of energy efficiency improvement,” France, 2012.
[5] Institute for Dversification and Saving of Energy and Ministery of Industry, Energy and Tourism (IDAE), "National Plan of energy saving and energy efficiency 2011-2020," Madrid, 2011.

[6] Ministerio de Vivienda, Código Técnico de la Edificación, Madrid: Spain, Real Decreto 314/2006 de 17 de marzo and further modifications.

[7] Iberdrola, "Iberdrola.com," December 2016. [Online]. Available:

https://www.iberdrola.es/clientes/autonomos/electricidad/mas$10 \mathrm{kw} /$ plan-compromiso-pymes. 